\title{
JSL Fist Signs and NMS Information
}

\author{
Kazuyuki KANDA, Chukyo University
}

\begin{abstract}
Sign languages are visual language and their grammatical phenomena are often represented in space. The prosodic elements in sign languages named Non-Manual Signals such as facial expressions, postures or other body movements behave as those prosodies in vocal languages. The learners of sign language in general believe that a hand-shape takes the most important role in sign language. This paper proves it is not true and that NMS is a crucial element of communication in sign language. In our experiment, a hand-shape is fixed as a fist, so called 'Doraemon hand'. It is observed that signing by a fist hand shape is still communicable, and in stead other elements are replaced or emphasized.
\end{abstract}

Keywords: Doraemon signs, Fist signs, Non־manual Signals, sign language

\section{1. 序}

手話は原則的に音声を使用せず、空間上に構成素を配 列する視覚言語である。音素に相当する手のかまえ、位 置、動きは身体によって表現される。

一般に手話は手の動きによる表現だと考えられがちだ が、実際には表情が重要な位置を占め、さらに姿勢の変 化など身体全体を使って表現される。そのことはまた多 数の構成素が 3 次元空間上に同時に発現されるだけでな く、音声配列のような 1 次元的配列もなされるため複雑 な表現形式となる。

手話学習者のほとんどは手の形（手型）に多くの関心 を払い、細かな違いを気にする傾向にあるが、万ら者の 手話では手型は崩れることが多く、また発信速度が速い ろう者の手話を手話学習者が読み取りにくい原因の 1 つ となっている。自然速度の手話表現には弱形(weak forms)や縮約(reduction)があるが、本論ではその実態を 知るための研究の一部として、手型を拳に限定した手話 表現（いわゆるドラえもん手話）の特徵を分析した。

\section{2. ドラえもん手話と能面手話}

手話の音素の 1 つである「手のかまえ」は手型と局所 運動に分けられる。その手型を固定した場合の影響を探 るのが本論の目的である。

從来、手型を固定した表現（ドラえもん手話）と表情 を固定した表現（能面手話）では前者が後者よりはるか
に伝達力があることが経験的に知られている。実際、手 に障害がある人の手話はコミュニケーションにほとんど 支障はないが、表情の乏しい聴者の手話はわかりにくい という現象が一般に見られる。音声言語では表情はノン バーバル・コミュニケーションとして扱われ、一般に感 情や心理的状態を表出する。手話でも感情や心理状態は 表情にも表れるが、一方、表情は文法としても利用され るため、手話の習熟者以外には両者の識別が困難である。

それを実験により解明する手だてとして、表情がまっ たく表出されないように面をかぶって手話をすると、き わめて伝達効率が落ちるが、グローブをはめるなどして 手型を固定しても伝達効率はほとんど落ちない。手話に おけるNMSの重要性が指摘される。

\section{3. 弱形と縮約}

音声言語学習では基本として書き言葉の発音を学習す る。それが強形(strong forms)だが、実際の会話では変 化した形である弱形(weak forms)が用いられる。また単 語の連結により同化(assimilations)が起きたり、縮約( reductions)が起きたりする。一般に語学教育ではこれら の話し言葉の特徽が教えられないため、学習者の多くが 「生の表現」をなかなか間き取れないでいる。一般の学 習者はこれをスピードだけの問題と考えているため、ゆ っくり話してもらうことを希望するが、実際には速度を 落としても理解できない。同様に手話にも強形と弱形が あることは専門家にもほとんど知られていない。 


\section{4.ドラえもん手話の実例}

この例は手話のジョークであり、手型を固定すること による誤認を題材にした手話のコントであることをまず 理解しておか子执がならなっこのコントの「落ち」は「映 画」の手話は平手を目の前で上下させるのが標準形だが、 平手を拳に変えて上下させたため意味が暧昧となり相手 は「乳撨り」と誤認する部分にある。映画と乳搾りの誤 解がギャグである。本論にとって重要なのはこの「落ち」 以外の部分が拳による固定手型でもほとんど伝達できて いることにある。伝達可能な理由としてNMSが活用さ れている、文脈による推定がある、などがあるが、手型 が固定されることで、運動が強調されたり、局所運動が 転移するなどの現象が見られる。

もう】つのギャグは「久しぶり」と「新聞を読む」が 同表現になるためのおもしろさだが、こちらは話の中で 誤解が解かれる。

\section{5。転移と言い換え}

「あいさつ」という手話は標準形では両手のひとさし 指を向かい合わせにし、ひとさし指を曲げる表現である。 ドラえもん手話ではこれを手首を曲げる表現に変化させ る。指曲げを手首曲げに転移させた例であり、同じ局所 運動間の転移である。

言い換えも行われる。「久しぶり」を「新聞」と誤認し た側が別の新聞という手話を用いたり、新聞紙を破るパ ントマイムをすることで相手に理解させている。

\section{6. 拳の意味}

英語母音が弱化すると schwa と呼ばれる母音になる ことが知られている。手話において、手型を形作る筋肉 を脱力させると拳に近い形となる。実際、万う者手話で は弱化する部分はその形になる。あるいは拳をゆるめた 形が schwa の機能を果たしているのかもしれない。しか し別の実験ですべてを平手にする、すべてを1本指にす るなどをしてみると、平手や 1 本指でもかなり伝達力が あることがわかる。またアメリカでは I-LOVE-YOU の 手型だけの手話表現遊びがある。これらの現象を総合す ると、手型は音声言語の母音の機能よりはるがはさな 機能をもっていると想像される。

\section{7. 結び}

本論は手話の手型を固定化することで、手型のもつ役 割とNMSとの関倸を示した。また局所運動の転移の例 を示した。一般に語学では強形の学習から始め、弱形の 学習は慣れによる経験に頼っている。弱形学習を導入す ることで生の言語活動を理解するための実践的言語力を つけることが可能であることは英語教育では広がってい るが、手話では皆無である。本論では弱形研究の端緒と して、ドラえもん手話の実例を紹介し、手型を固定して
も伝達効率がほとんど落ちないことを示した。これは手 型がほとんどすべて弱化した状態を人工的に作りだした ものと考えられる。弱化しないのは元々手型が拳である 表現だけである。1つひとつの手話単語の強形と弱形の リスト作成は今後の研究課題であるが、本論の研究を元 に手型の詳細にこだわらないNMS 学習を中心とするカ リキュラム構成は手話学習改善に役立つと思われる。

\section{参考文献}

1) ビデオマガジン「SEE」テスト版 末公開 1995

2) Kazuyuki Kanda, Yuji Nagashima, Mina Terauchi, Daisuke Hara and Akira Ichikawa: Lexicon of Sign Language: Lexical Structure of Japanese Sign Language. Proceedings of Linguistics and Phonetics 2002. pp. $47-48$

3) Mina Terauchi, Yuji Nagashima, Kazuyuki Kanda: Constraints on co-occurences of manual and non-manual operations in JSL International Conference on Information Technology \& Applications(ICITA 2002) Kashika, T. : Visualization Technique, VSJ Press, Tokyo (1997) pp. 1111-1125.

4）神田和幸·市川熹·長嶋祐二加藤雄士 ·寺内美奈・原 大介 佐藤昌延、渡邊勇夫 “时本手話の非手指信号の統計的分析 - sIGNDEX V.2 中間報告—”第27回日本手話学会大会、 pp.24-27, (2001.6)

5) KANDA, Kazuyuki, ICHIKAWA, Akira, NAGASHIMA, Yuji, KATO, Yushi, TERAUCHI, Mina, HARA, Daisuke, MUTO, Daishi, SATO, Masanobu, WATANABE, Isao, "Notation System and Statistical Analysis of NMS on JSL", Gesture Workshop 2001, 4-1(2001.4)

6）神田和幸、市川 喜、長嶋祐二他: 日本手話の非手指動作信 号の㓍計的性質一 sIGNDEX V.2 解析作業中間報告”ヒューマ ンインタフェース学会研究会報告集、Vol.2 No.5,pp5-10 (2000. 12)

7) Kazuyuki Kanda, Akira lchikawa, Yuji Nagashima, Yushi Kato, Mina Terauchi," Signdex V.1 \& V.2, The Computerized Dictionary of Japanese Sign Language: the notational system and the images of JSL", "th International Conference on Theoretical Issues in Sign Language Research, July $23^{\text {rd }}-27^{\text {th }}$, 2000, Amsterdam, The Netherlands, p.65

8）神田和幸、市川喜、長嶋祐二、加藤雄士、寺内美奈, 传藤昌 延、“SIGNDEX V.2 による手話文記述法に関する検討”、通信 学会 福祉情報工学研究会 WIT00-7, pp.37-42 (2000.5

9) Kazuyuki Kanda, Y. Nagashima, A.Ichikawa et al. "A Proposal of the Standard Labelling System for JSL:Signdex V.1", $7^{\text {th }}$ International Conference on Human-Computer Interface, 1997.

本論は平成 14-17 年度科学研究費補助金基盤研究 (A) (1) 課題番 号 14208017「コーパスと統計的手法を用いた手話解析とその手 話教育一の応用の研究」研究代表者神田和幸及び平成 14-17 年 度科学研究費補助金萌芽的研究課題番号 14651098 「手話の言語 技能としての評価法の研究」研究代表者神田和幸、平成 14 年度 中京大学特定助成費課題番号 221104 研究代表者神田和幸によ る研究成果の一部である。 